\title{
A EVOLUÇÃO DO PODER NAS ORGANIZAÇÕES
}

\section{Carlos Osmar Bertero*}

A Teoria Clássica de Administração, utilizando-se adequadamente dos princípios da economia clássica, julgou ser a tarefa fundamental da teoria da oragnização, a fim de propiciar à administração os foros de ciência, que se procedesse pela utilização do princípio da divisão do trabalho. $\mathrm{O}$ movimento de Administração Científica de Frederick W. TAYLOR, e grande parte do esfôrço de teorização dos clássicos, foi no sentido de "racionalizar" o trabalho, desenvolvendo recursos para a medição e simplificação do esfôrço humano, e de dividir as tarefas, ou seja, os trabalhos a serem realizados, departamentalizando-os. Isto fêz com que a propositura clássica para a teoria da organização se transformasse em sinônimo de departamentalização. A contribuição de G. ElToN MAYo à teoria da oragnização não chegou a questionar fundamentalmente a "organização formal" e sua departamentalização, mas simplesmente tendeu a introduzir novas variáveis para o entendimento do problema das tensões organizacionais, na medida em que chamou a atenção sôbre a "estrutura informal" e sôbre o papel a ser desempenhado pela administração de cúpula na compreensão e manipulação da dinâmica do "pequeno grupo".

* Professor-Adjunto do Departamento de Administração Geral e Relações Industriais da Escola de Administração de Emprêsas de São Paulo, da Fundeção Getúlio Vargas. 
Administrar continuaria sendo, mesmo após a contribuição de MAYo, organizar, entendendo-se pela adjetivação, dividir tarefas, atribuindo-as a departamentos da emprêsa, e comandar, fazendo com que as ordens fôssem cumpridas, não através do mecanicismo autocrático clássico, mas levando em conta as componentes do comportamento individual, à luz do papel desempenhado pelos "grupos primários" e pela "organização informal" da emprêsa. O que se procuraria aprimorar na estrutura clássica seriam as técnicas de comando, mormente a maneira de procederse à delegação, a fim de que o mecanismo diretivo pudesse ser implementado. Parte importante em tal processo seria o estudo da estrutura organizacional mais conveniente, se centralizar ou descentralizar. $O$ aumento do tamanho físico das fábricas, primeiramente, e, depois, o crescimento da complexidade das atividades fizeram com que se impusesse a preocupação não apenas com delegar, mas, também, com saber de que modo e até que ponto seria conveniente delegar e qual a amplitude e o objeto das delegações, ou seja, do que centralizar, do que descentralizar e até que ponto seria conveniente usar um e outro recurso. Nesta conjuntura, a delegação e as cognatas centralização e descentralização apareceriam como as "muletas" de que se serviria a ação administrativa para ensaiar os seus primeiros passos.

Pouca atenção se deu, até, pràticamente, o fim da Segunda Guerra Mundial, aos aspectos da atividade administrativa enquanto "tomada de decisões". Data desta época o livro de Herbert Simon, O Comportamento Administrativo, onde pela primeira vez os "princípios" da escola clássica são acerba e lògicamente criticados, e onde é proposto o processo decisório enquanto centro e ponto de partida para a formulação de uma teoria da organização. $O$ aumento na complexidade organizacional, que surgiu com os novos sistemas de comunicação e de registro de informações, através dos computadores, e a maior manuseabilidade, que as referidas máquinas conferiram aos dados acumulados. 
agiram no sentido de aumentar o cêrco em tôrno do processo de "tomada de decisões". Embora reconheçamos que o processo decisório seria demasiadamente estreito, como de uma teoria da organização, acreditamos que ninguém questionaria a sua fundamental importância em nossos dias. $O$ aspecto decisório na vida das organizações não constitui preocupação exclusiva dos administradores de emprêsas, mas tem levado cientistas políticos, psicólogos e lógicos a se colocarem aproximadamente as mesmas questões.

O interêsse reside não apenas em saber como são tomadas as decisões pelas pessoas em elevadas posições na administração de organizações econômicas e governamentais, mas, também, em tentar aferir a possível correção ou incorreção das decisões tomadas. Que no "processo decisório" sempre estivemos no terreno do provável, e não no do certo ou do errado, sendo até o momento impossível lidar com o "verdadeiro" e o "falso" tal que nos vem da lógica formal, são coisas que ninguém questionou. $A$ indagação que os estudiosos do "processo decisório" levantaram foi no sentido de saber-se até quando continuaríamos a nos mover exclusivamente no universo do provável. Não apenas uma revisão histórica de como tem evoluído o problema da decisão torna-se importante, mas inclusive estudá-lo de maneira empírica, isto é, utilizando os passos metodológicos clássicos do método experimental: ir aos responsáveis e observar, de maneira metodològicamente aceitável, a maneira pela qual agem durante as tomadas de decisão. Atualmente, tal tipo de procedimento como abordagem do processo decisório vem sendo desenvolvido por alguns professôres do Massachussets Institute of Technology (MIT) e bom exemplo desta metodologia pode ser encontrado no artigo de PEer Soelberg, Unprogrammed Decision Making. ${ }^{1}$

\footnotetext{
1 SoElberG, Peer, Unprogrammed Decision Making, in Research Toward the Development of Management Thought, São Francisco, The Academy of Management, 1967, p. 3 a 11.
} 
Acreditamos ser viável tentar um esbôço do histórico do processo decisório, acompanhando, para tanto, os mesmos caminhos e pontos fundamentais seguidos, até o momento, pelos historiadores da teoria da organização.

No livro Organizations, de J. MARCH e H. Simon, a escola clássica, e particularmente o movimento de Administração Científica de F. W. TAYLOR é caracterizado como sendo uma aplicação da fisiologia, ou do limite e capacidade fisiológica ao estudo do trabalhador e do trabalho a realizar. ${ }^{2}$ Ainda na escola clássica, encontramos os teóricos da departamentalização (GULICK HALdANE, FAYOL e MOONEY) que se ocupavam em transcender os muros da fábrica, aos quais TAYLOR definitivamente havia circunscrito os seus movimentos para tentar, num esfôrço mais amplo, incluir tôda a atividade e os demais setores da emprêsa. ${ }^{3} \mathrm{O}$ esfôrço de departamentalização consistiria em delinear uma série de atividades desempenhadas no interior da emprêsa e grupá-las segundo algum critério. A semelhança entre os vários tipos de atividade pode ser um critério, como na decisão de criar um pool de secretárias para atender um determinado número de executivos, ao invés de permitir que cada um tenha sua secretária particular, pela utilização do conceito de função que, na época, havia sido introduzido em psicologia por E. CLAPAREDE e seus seguidores - e outro, a natureza dos processos industriais utilizados na produção de um bem ou numa linha de produtos e que seriam, em grande parte, ditadas pelo tipo de equipamento utilizado.

Tôdas essas maneiras de encarar o problema da teoria da organização deixavam de lado o processo decisório e a sua locação na estrutura formal da emprêsa. Uma tentativa de olhar para o problema seria a partir do próprio conteúdo ideológico das teorias de organização, tão bem

: MARCH, James G. e Simon, Herberth A., Organizations, Nova Iorque, John Wiley \& Sons Inc., 1963 , p. 12 a 17.

I Idem, ibidem, p. 22. 
estudadas por ReINHARD BENDIX ${ }^{4}$ e que podem servir para delinearmos as grandes linhas do processo decisório no interior da emprêsa no período da escola clássica.

A escola clássica refletiu num plano ideológico, e mesmo social e político, o triunfo de uma burguesia industrializadora nos países da Europa Ocidental e nos Estados Unidos. A ideologia dessa "elite industrializadora" já foi exaustivamente estudada por economistas, sociólogos, psicólogos e cientistas políticos, de cujas conclusões a teoria das organizações tem se utilizado com grande freqüência. Sendo a "elite industrializadora" portadora de tôdas as virtudes positivamente sancionadas pela sociedade, segue-se que lhe cabe uma posição hegemônica, não apenas na economia como um todo, no estabelecimento da política e na luta pelo poder, mas, também, no interior das emprêsas que criou e que dirige de maneira quase absoluta. $O$ conteúdo ideológico da escola clássica atribui ao entrepreneur atributos que $o$ distinguem qualitativamente dos subordinados, operários, bem como dos administradores de nível médio e escriturários. Nada mais lógico que enfeixasse em suas mãos não apenas os procedimentos, mas o processo decisório em sua totalidade. A tomada de decisões exigia um grau de discernimento e uma capacidade para perceber os fatos e agrupá-los que não constituíam atributo dos que ocupavam os estratos inferiores da pirâmide organizacional. O caráter mecanicista da escola clássica pode ser visto como corolário dessa implicação, ou seja, a mecanismo organizacional, o autocratismo, a rigidez escalar, são conseqüência da capacidade de uma minoria para decidir. O fato de apenas uma minoria ser capaz de tomar decisões acaba por ditar a estrutura piramidal da organização.

Portanto, apenas os que ocupavam o tôpo das emprêsas é que decidiam e o faziam pelo monopólio sôbre as informações necessárias para nortear a decisão — uma vez que

\footnotetext{
- BENDIX, Heinhard. Work and Authority in Industry; a study on the ideologies of management in the course of industrialization, Nova Iorque, Harper Torchbooks, 1963.
} 
o volume de informações era sensìvelmente reduzido no período de "explosão industrial" que marca as primeiras etapas da industrialização nos países hoje industrializados, - e pela relativa incapacidade dos ocupantes de posições subalternas. Talvez não ocorra, aos que falam muito da inconveniência da não delegação e da centralização de tôdas as decisões no tôpo das emprêsas, que a quase totalidade dos ocupantes de posições, mesmo a nível de média administração, não estariam capacitados para tomar decisões. Não se trata de endossar aqui a diferença de atributos entre administradores e administrados, adjudicando aos primeiros superioridade qualitativa sôbre os segundos, mas simples constatação da situação vigente num momento determinado do processo de industrialização. Um dos elementos a forçar a delegação e fazer com que se exerça pressão no interior das emprêsas para que níveis inferiores, mormente a administração média, recebam parte da responsabilidade pelo processo decisório, origina-se no fato de ter ascendido bastante nas sociedades industriais, nas últimas décadas, o número de pessoas que por meio da democratização do ensino, principalmente o superior, têm acesso a um treinamento que as torna mais capazes de assumir parte do processo decisório no interior das emprêsas, à medida em que se necessite de conhecimento técnico e especializado.

Esta "democratização" de oportunidades constitui mais uma consequiência do que uma causa do processo de industrialização, e, nos momentos em que se implantava o processo de industrialização, a maioria da população ainda era analfabeta, poucos eram os que tinham um nivel médio de educação, e o cursar universidades constituia privilégio definitivo das classes econômicamente poderosas. Portanto, as funções de média administração, para não falar de escriturários e operários, eram exercidas por pessoas cujo grande instrumento de capacitação profissional era a alfabetização. Em nosso país, ainda podemos encontrar esta situação, nas pequenas e médias emprêsas, onde o chefe do escritório, o contador, o encarregado do 
pessoal, são bàsicamente pessoas que dominam muito poucos instrumentos de obtenção de informação, e são pouco treinados para poder participar do processo decisório, sendo a alfabetização o único qualificativo que os libertou do trabalho braçal.

Outro fator decisivo para que o processo decisório permanecesse circunscrito aos administradores de cúpula era a natureza do contrôle, na emprêsa capitalista dos primórdios da industrialização. Já foi suficientemente estudada por especialistas americanos, mormente juristas, o que se chamou de Corporate Revolution, ou seja, a modificação substancial no contrôle acionário da maioria das grandes emprêsas. Vicissitudes, que não cabe relacionar nos limites dêsse artigo, fizeram com que se processasse a "democratização" do capital das grandes sociedades anônimas. Em têrmos administrativos, isto passou a significar uma divisão de atributos entre dois grupos: os proprietários de ações, em grande número, o que acarretava a atomização do capital, e de outro lado, a emergência de "administradores profissionais" que passavam a ter, se não a posse, pelo menos o uso efetivo do patrimônio das grandes emprêsas. Os acionistas, jurìdicamente proprietários das sociedades anônimas, afastavam-se cada vez mais das operações das emprêsas que possuíam, até que se afastaram de vez, limitando sua participação ao envio de proxies aos diretores em exercício para que êstes utilizassem o direito de voto de cada acionista para eleger quem lhes parecesse mais capacitado e cuja presença nos quadros diretivos da emprêsa apresentasse maior conveniência. Isto levou, inevitàvelmente, a que um determinado grupo (managers, burocratas de partido, ou tecnocratas de qualquer formação) viesse a colocar-se no núcleo de poder das emprêsas e a perpetuar-se nas posições de mando.

A evolução na tecnologia e na maneira de administrar a emprêsa moderna acarretaram, por sua vez, outras cadeias de argumentos em prol da descentralização administrativa e principalmente na modificação da própria estrutura do 
processo decisório. De um lado, assistiu-se ao aumento do tamanho físico das grandes sociedades anônimas. Grande parte das emprêsas industriais surgiram para fabricar um determinado produto que havia sido "inventado" pelo próprio empresário, ou para aplicar um nôvo processo, também inventado ou desenvolvido pelo empresário. (São bons exemplos o nôvo processo de fabricação de soda cáustica que levou ao aparecimento da $\mathrm{Du}$ Pont e que foi desenvolvido por IRINÉE DU PONT nas primeiras décadas do século XIX, e a linha de montagem para automóveis, por HENRY FORD.)

Com o tempo, estas emprêsas ou aumentaram a sua linha de produtos, passando a produzir centenas e até milhares de produtos em fábricas espalhadas não apenas nos países de origem, mas estendendo-se por todo o mundo, até a criação de várias fábricas para produção de um único produto. Isto tudo levou a que a centralização do processo decisório, apanágio da época do capitalismo industrial clássico, passasse a dar mostras de ineficácia administrativa. É o momento em que a manutenção de tôdas as decisões na cúpula administrativa passa a dar maus resultados porque, pelo menos, se coloca a impossibilidade física de remeter, em tempo hábil, aos administradores de tôpo, tôdas as informações sôbre as atividades da emprêsa. Esta fase dos problemas administrativos das grandes emprêsas foi pouco estudada. E possivel encontrar, todavia, no excelente livro de Alfred Sloan JR., Minha Vida na General Motors, um relato da vida da grande emprêsa, desde suas origens até pràticamente os nossos dias, e das dificuldades bastante sérias enfrentadas ao longo da década dos vinte e nos primeiros anos da década dos trinta, quando o crescimento aliado a uma estrutura administrativa ainda centralizada e com o processo decisório circunscrito ao nível da diretoria e do Board of Directors tornavam impossivel sequer o contrôle das atividades empresariais. Bastante interessante de ser observada é a crise surgida por volta de 1920 , quando era impossível ao Board obter um saldo consolidado das Contas a Pagar a curto prazo. Uma análise mais acurada 
do problema administrativo da General Motors pode ser encontrada no livro de Peter DRUCKer, The Concept of the Corporation, publicado logo após a Segunda Grande Guerra, onde está registrada grande parte da experiência do professor e consultor americano quando de sua permanência na GM.

A.lém dos problemas de simples tamanho, que forçaram a revisão das práticas decisórias, tivemos o problema da complexidade tecnológica crescente. $\mathrm{Na}$ verdade, o aumento da complexidade em muito contribuiu para que se procedesse à revisão da estrutura organizacional da emprêsa, com base na modificação das práticas decisórias, ou seja, pelo desenvolvimento da técnica de coletar e processar informações, num primeiro momento, com o aperfeiçoamento de sistemas contábeis e o desenvolvimento de máquinas mais complexas e rápidas, e, num segundo, com o aparecimento dos computadores eletrônicos, que vieram revolucionar o sistema de coleta e de treinamento de informações nas organizações de nossos dias.

$\overline{\mathrm{A}}$ fim de fazer face aos novos problemas levantados com o aumento do tamanho das emprêsas, de um lado, e com o aumento da complexidade tecnológica, de outro, duas tentativas foram sugeridas, ao nível de modificações na estrutura organizacional das emprêsas, sendo relatadas por P. DRUCKER. Todavia a colocação de DRUCKer é ainda clássica, podendo ser perfeitamente enquadrada num capitulo sôbre departamentalização ou centralização e descentralização de um Manual Clássico de Administração. Os seus conceitos são bàsicamente dois, o de descentralização federal e o de descentralização funcional. $\mathrm{O}$ primeiro consiste em aplicar à vida de grandes sociedades anônimas - que poderiam ser hoje caracterizadas como emprêsas multinacionais ou internacionais e que, não raro, contam sua linha de produtos aos milhares, possuindo dezenas e até centenas de fábricas localizadas em vários países - o conceito de federação, tal qual se aplica para definir alguns Estados modernos (Estados Unidos. 
União Soviética, Brasil, República Federal Alemã etc.) e que busca o velho ideal de unidade pela multiplicidade. A descentralização federal "é a que organiza as atividades em emprêsas autônomas, cada qual com seu mercado e produto e com responsabilidade própria quanto a lucros e perdas." ${ }^{5} \mathrm{O}$ exemplo, por assim dizer clássico, de descentralização federal poderia ser encontrado nas várias divisões da General Motors (Chevrolet, Buick, Cadillac, Oldsmobile, Pontiac, Frigidaire etc.).

A descentralização funcional é vista poi P. DRUCKER como uma alternativa menos fecunda administrativamente, a ser aplicada apenas quando a federal não fôr viável. Êle a define como aquela "... que estabelece unidades integradas com total responsabilidade por uma etapa, distinta e importante, do processo de produção" ".

No sistema de descentralização federal, largamente utilizado nas grandes sociedades anônimas contemporâneas, o processo decisório sofre uma revisão completa, quando comparado com o que era na emprêsa industrial clássica. $\mathrm{Na}$ verdade, a cada unidade "federada" se concede autonomia operacional, e freqüentemente até para a elaboração de diretrizes (policy making), restando à Diretoria e ao Board a elaboração das diretrizes mais abertas da emprêsa, que devem nortear o estabelecimento de diretrizes de tôdas as unidades federadas e um contrôle bastante amplo que se faz sentir particularmente na aprovação de peças financeiras de grande importância, como por exemplo, o Orçamento de Capital da Sociedade Anônima. Restarão ainda, para a Diretoria e para o Board, o contrôle e a administração imediata de alguns setores considerados de grande importância estratégica para o desenvolvimento futuro da organização, como os modernos departamentos de Pesquisa e Desenvolvimento de Novos Produtos $(R \& D)$, que pela sua importância e pelo sigilo que cer-

o Drucker, Peter, A Prática da Administração de Emprêsas, Rio de Janeiro, GB, Editôra Fundo de Cultura, 1962, Vol. 2, p. 28.

Idem ibidem, p. 29. 
cam suas atividades, e também pelos grandes investimentos que para êles são canalizados, tornam conveniente uma subordinação direta ao tôpo da pirâmide organizacional.

Da maneira pela qual se coloca o processo decisório na moderna emprêsa podemos afirmar, com grande margem de segurança, que se apresenta como uma atividade que exige o concurso de todos os membros da organização. Embora a estrutura formal continue a expressar-se em organogramas de forma piramidal, o importante é que a pirâmide mostra mais uma distribuição de atividades e de vários níveis de tomada de decisão do que pròpriamente um centro decisório, como ocorria com a cúpula da emprêsa clássica, sendo os demais níveis executores de decisões tomadas na cúpula. Os níveis mais baixos da pirâmide organizacionai não funcionam tão-sòmente como implementadores de decisões tomadas, mas contribuem, em larga medida, para que a elas sejam tomadas. Primeiramente, existe um limite para o processo decisório por parte das unidades "federadas". Poderíamos tomar um exemplo vindo do Orçamento de Capital, onde uma unidade A está automàticamente autorizada a decidir sôbre investimentos que montem até determinada quantia, podendo apenas recomendar a níveis superiores o que ultrapassar a quantia prefixada. Todavia, os dados que norteiam o processo decisório de níveis superiores são supridos pelos níveis inferiores, ou unidades "federadas", e hoje em dia o suprir dados não significa transferir matéria-prima de informações, mas fornecer dados já passa a incorporar a análise, interpretação e seleção dêsses dados, o que representa um bom número de decisões. Não queremos dar a entender que a cúpula das emprêsas se limitaria a sancionar decisões tomadas nas várias unidades "federadas", mas que a descentralização constitui uma participação de um maior número de unidades, o que equivale a dizer pessoas, no processo de tomada de decisões. Uma das grandes revoluções nas organizações, em nossos dias, e que talvez ainda não tenha sido percebida em tôda a sua extensão e pro- 
fundidade, é que tôda a organização passou a operar como um corpo decisório, absorvendo atributos que anteriormente estavam reservados aos diretores e conselheiros. $O$ economista norte-americano JoHN K. GALBRAITH apontou recentemente esta mudança na estrutura organizacional, como o complemento de um ciclo, onde o poder pertenceu sucessivamente à terra, para passar ao capital, no período do capitalismo comercial e mais decididamente, com o capitalismo industrial, para, numa etapa seguinte, encontrar os managers, que poderíamos traduzir por administradores de profissão e, finalmente, a uma equipe, formada por administradores e tecnocratas das mais variadas formações, que se caracteriza pela necessidade de equipe para levar adiante a vida organizacional, marcando uma nova etapa no processo de tomada de decisões. ${ }^{7} \mathrm{O}$ que caracteriza a etapa atual é a impossibilidade de um pequeno número de pessoas, colocadas na cúpula de uma emprêsa, vir a conduzi-la, pelo simples fato de a complexidade organizacional impedir que tal ocorra. $\mathrm{Na}$ verdade, a própria dominação dos managers já surge como uma etapa superada no processo, na medida em que o administrador se apresenta sempre como um generalista, e o processo decisório exige crescentemente a presença do especialista. Os atributos do administrador, enunciados por HENRY FAyol no seu livro Administração Geral e Industrial, podem nos encaminhar, sem maiores percalços ou problemas de consciência, à conclusão de que se trata, indiscutivelmente, de um tipo ideal, mas que se deve esforçar por não saber nada a respeito de tudo. Tal concepção do administrador foi aceita quase sem discussão até recentemente, quando administrar significava capacidade de vislumbrar soluções a partir de dados incompletos, pois os dados eram fatalmente mais incompletos do que são hoje para a tomada de decisões. Basta que nos recordemos de quão exíguas eram as informações sôbre o mercado

7 Galbraith, John K., Autoridade e Organização na Emprêsa Moderna, Perspectivas sôbre o Poder Econômico, in Revista de Administração de Emptêsas, Rio de Janeiro, GB, Fundação Getúlio Vargas, Vol. VIII, n.o 26. 
há apenas três décadas, e da massa de informação de que hoje dispomos em muitos países. Além disso, o administrador se impunha mais por traços de personalidade, equilíbrio, senso de adequação, firmeza, eqüidade etc., do que pelo manuseio de técnica ou técnicas. Estas eram, aliás, mal vistas por um homem que pretendesse ser, pelo menos, um aspirante a administrador. $O$ domínio da técnica estava reservado a profissionais vários, que deveriam dedicar tôda uma vida profissional a fim de aplicá-la e possìvelmente melhorá-la, mas não deveria causar maiores preocupações ao administrador.

Foi nas grandes emprêsas, e mais especificamente após a Segunda Grande Guerra, que o problema do generalista versus especialista passou a tornar-se crítico. $\mathrm{Na}$ verdade, as primeiras manifestações de tensões entre administradores generalistas, que controlavam as decisões das organizações, e os especialistas, que não detinham poder decisório, surgiram em organizações não econômicas, ou seja nas Fôrças Armadas dos Estados Unidos. Isto porque, pela primeira vez, um corpo de especialistas dos mais destacados foi colocado sob as ordens de generalistas, no caso, oficiais das Fôrças Armadas dos Estados Unidos, para que trabalhassem no projeto Manhattan. Posteriormente, ou seja, quando um número crescente de especialistas teve que ser pôsto sob as ordens de oficiais das Fôrças Armadas, que não estavam inteirados dos complexos problemas científicos envolvidos na pesquisa para eventual desenvolvimento de novas armas, a tensão não fêz senão aumentar.

Um relato interessante do tipo de atrito surgido, embora não aborde especificamente $o$ aspecto decisório que ora nos ocupa, pode ser encontrado no livro de ROBERT Presthus, The Organizational Society. Para maiores indagações sôbre a lacuna generalista/especialista, é de todo conveniente a leitura do livro de VICTOR THOMPSON, Modern Organization. ${ }^{8}$

8 O livro foi recentemente traduzido pela USAID com o título Moderna Orßanização. 
A solução para o problema não poderia ser outra senão a crescente importância dos especialistas, enquanto partícipes do processo decisório. Enquanto relacionamento tenso entre generalistas e especialistas, nada mais conveniente do que mencionar as vicissitudes por que têm passado o pedagogo e administrador escolar, ao que tudo indica brilhante, JAMES WEBB, na direção da NASA (National Air and Space Administration), agência responsável, entre outras coisas, pelo programa espacial norte-americano.

O CASO BRASILEIRO

As observações que realizamos até o momento são pertinentes a uma estrutura organizacional que se apóia em economias desenvolvidas, ou dos chamados países cêntricos. O mesmo certamente não pode ser transferido para países subdesenvolvidos, onde a problemática organizacional ainda não logrou tal configuração, por fôrça de ausência de liderança que levasse ao desenvolvimento de nova tecnologia e de criação de novos produtos. As regiões periféricas limitam-se a importar, com maior ou menor atraso, os produtos e as inovações tecnológicas dos países cêntricos e, conseqüientemente, suas mudanças organizacionais.

No Brasil, o quadro apresentar-se-ia de maneira relativamente simples e creio que não faltaríamos muito para com a verdade se o reduzíssemos a três tipos fundamentais.

Primeiramente, teríamos as emprêsas pròpriamente brasileiras, ou sejam, de propriedade de grupos brasileiros e que se caracterizam pelo contrôle acionário de um pequeno grupo, em geral também ligado por vínculos de natureza familiar, onde o processo decisório tende a refletir os mores de uma sociedade tradicional, em nosso caso, o paternalismo autocrático. O processo decisório no interior da emprêsa tenderá à repetição dos padrões de comportamento familiar, ou seja, haverá uma grande concentração de decisões a nível de diretoria, os níveis mais baixos não 
terão participação no processo decisório e limitar-se-ão a funcionar como organismos executores. Isto não significa que inexistam pessoas capacitadas nos vários setores da emprêsa. Freqüentemente, o aumento de complexidade organizacional e a maior oportunidade que se oferece para obtenção de graus universitários nos grandes centros urbanos, pelo menos, permitirão que se encontrem funcionários com nível universitário nas emprêsas familiares brasileiras. O que, todavia, importa é que tais indivíduos não são chamados a participar ativamente no processo decisório porque se mantém ainda a relação patrão/empregado, com tôdas as conotações que possui numa sociedade tradicional. Mesmo que altamente capacitado, dominador de uma técnica ou de habilidades específicas, não raro decisivas para a própria continuidade das atividades da emprêsa, o nosso universitário será sempre empregado, e deverá manter, com relação aos diretores, a atitude de deferência que se espera de um subordinado numa estrutura patriarcal tradicional. Outro elemento importante a ser observado é o da motivação dos homens que ocupam posições fora da diretoria, ou seja, do quadro de proprietários. Por ser a emprêsa fechada e, no caso, o acesso às posições de cúpula estar condicionado à posse de contrôle acionário, estas pessoas sabem que têm suas possibilidades de acesso bastante diminuídas. É muito difícil que um não proprietário ascenda a uma posição de cúpula e mesmo que tal ocorra, em nossa estrutura empresarial, isto sempre significará uma diretoria de segunda categoria, que, freqüentemente, não chega a se distingüir para fins práticos - no caso, para tomada de decisões, no nível de pura gerência. A impossibilidade de chegar ao tôpo tende a desenvolver um padrão de indiferença como forma de comportamento organizacional. Evidentemente, ainda existe uma segunda colocação para o especialista, ou para o homem que possui um nível superior de educação na emprêsa familiar brasileira: será colocá-lo num cargo de assessoria. Tal parece ser inclusive uma posição cômoda, 
pois satisfaz a emprêsa, à medida que obtém os serviços de um homem de alto nível, e elimina os inconvenientes de ter que lhe atribuir autoridade linear na organização.

O processo decisório tenderá a fazer com que grande massa de informações suba fatalmente aos diretores-proprietários e êstes usarão ou não a assessoria, mas nunca chegarão a transformar suas emprêsas numa verdadeira "equipe para tomar decisões".

Uma segunda categoria é a emprêsa estrangeira que opera no Brasil e que tem seus quadros de dirigentes selecionados e enviados pela casa matriz. O processo decisório não deixa de refletir uma atitude de colonialismo empresarial, na medida em que abre aos brasileiros apenas as posições intermediárias e ainda bastante esvaziadas de poder decisório. A êste respeito, é interessante observar que a emprêsa estrangeira não repete no Brasil, e nos demais países subdesenvolvidos em que se instala, a atitude revolucionária que apresenta no seu país de origem. Se funciona no seu país de origem como instrumento de renovação, a face que mostra aos países subdesenvolvidos é bastante diversa, ou seja, tende a associar-se à oligarquia para assegurar possíveis privilégios, e mantém um padrão de centralização na tomada de decisões. Tal formulação é inteligível, à medida que a subsidiária ou filial de uma emprêsa estrangeira num país subdesenvolvido tende a ser simples executora de tecnologia e de decisões tomadas nos países de origem.

Na verdade, não cabe à subsidiária localizada num país periférico a inovação tecnológica, pois pressupõe uma infra-estrutura econômica e educacional não encontrável aí. A inovação tecnológica e o desenvolvimento de novos produtos no moderno sistema empresarial resultam da conjugação de esforços de três instituições, a saber: o govêrno, a emprêsa e a universidade. $O$ primeiro, em geral, arca com parte substancial dos gastos incorridos para a pesquisa e o desenvolvimento de novos produtos e nova 
tecnologia, e muitas vêzes é consumidor cativo da inovação que se produzirá. A universidade provê o talento, ou seja, o pessoal que ocupará na moderna emprêsa as posiçõeschave para criar e administrar as inovações. Finalmente, a emprêsa é a instituição que se transforma no centro do processo, alocando, de maneira econômicamente ótima, os vários fatôres.

Tal situação não pode ser repetida nos países periféricos e, portanto, êstes estão, pelo menos num futuro previsível destinados a continuar como executores de novos métodos, talvez adaptadores de tecnologia e de produtos, mas não tendo a capacidade para a inovação. Ora, à medida que a subsidiária de uma emprêsa estrangeira se limita a transferir tecnologia e produtos desenvolvidos no respectivo país cêntrico, tôda a sua estrutura organizacional molda-se a fim de cumprir com estas funções. A subsidiária deverá adaptar produtos e não criá-los, importar tecnologia e não desenvolvê-la, cumprir ordens e não tomar decisões.

Para ir-se ao campo mais concreto das relações matriz/ subsidiária, bastaria indagar-se do grau de autonomia de que desfrutam as subsidiárias. Ver-se-á que é bastante limitado. Seus orçamentos são todos aprovados no exterior, sua linha de produtos é estabelecida nos escritórios das matrizes e seus lucros, remetidos ou reinvestidos segundo decisão da matriz. O acionista que se precisa contemplar, e cuja remuneração é necessária não está nos paises periféricos, mas nos cêntricos. A diretoria será constituída de alguns brasileiros que não chegam a participar dos aspectos operacionais da emprêsa, ou de sua gestão pròpriamente dita, mas ocupam posições na mesa de diretores por serem suficientemente influentes junto ao govêrno a fim de poder obter privilégios ou favores para a emprêsa que formalmente dirigem, ou porque representam grupos nacionais, geralmente no setor financeiro, cujas boas relações seria estultícia não cultivar. 
O terceiro tipo de emprêsa a ser investigada em nosso país seria a emprêsa de economia mista, onde participação governamental, principalmente da União, acaba dando ao Govêrno Federal o contrôle efetivo do empreendimento. $\mathrm{Na}$ verdade, a emprêsa de economia mista ainda não recebeu dos estudiosos de administração a atenção que merece, dada sua relevância no cenário econômico e empresarial nacional. São emprêsas imensas, tanto em ativos fixos, como em volumes de vendas, e que exploram atividades básicas da economia. São criadas para cobrir exatamente aquêles setores onde a economia privada não pode adentrar, pelo volume do investimento e pelo largo tempo necessário à maturação do investimento.

A ausência de "dominação familiar" concede-lhe maiores oportunidades para que se afaste dos padróes administrativos e adote processos decisórios diversos daqueles relatados quando da emprêsa familiar. Todavia não impede que reflita o ethos de nossa cultura. Pode inegàvelmente atender à necessidade de realização de "política de clientela", e exemplos disto são encontrados, tanto no passado como no presente dessas emprêsas. Todavia, estas considerações estão ainda longe de exaurir o problema. A emprêsa de economia mista torna-se particularmente sedutora ao estudioso do processo decisório pelo fato de estar ìntimamente ligada ao núcleo de poder no Estado (o Govêrno) e de refletir as pulsações e as tensões internas do próprio núcleo político; por isso, tenderá a espelhar dramàticamente tanto as grandezas como as misérias da sociedade global.

Cumpre destacar, em primeiro lugar, que os seus diretores não são proprietários, o que indiscutivelmente os aproxima mais dos administradores profissionais do que dos administradores jus sanguinis. Todavia, seria incorrer em êrro pensar-se que se apresentam como representantes típicos de uma administração profissionalizada ou de uma tecnocracia, na medida em que são freqüentemente recrutados 
entre administradores de emprêsas privadas brasileiras, familiarmente constituídas e que tendem a levar para o seu cargo as suas experiências administrativas. Merece destaque o fato dessas emprêsas terem sido, desde o momento de sua criação, colocadas sob forte influência dos militares. Exemplo sobremaneira importante é a da Petrobrás cuja direção cabe tradicionalmente a oficiais do Exército. Além disso, a crescente importância dos militares na atual conjuntura brasileira e a sua designação para ocupar cargos até então normalmente lotados com civis farão com que o estilo administrativo que os executivos militares imprimem às suas emprêsas reflita inevitàvelmente o ethos da organização militar. Se tentarmos aprofundar um pouco mais o que deva ser entendido por estilo ou ethos militar, acreditamos encontrar resposta satisfatória se o caracterizamos como burocrático. O Exército é uma organização tìpicamente burocrática, e o "tipo ideal" de burocracia weberiana poderia encontrar ressonância se aplicado às organizações militares. Portanto, é possivel esperar de tal administração - em grande parte conduzida por militares ou, pelo menos, onde êles ocupam as posições de cúpula - uma valorização da organização formal, certa minúcia no tratamento dos problemas e a tentativa de regulamentação de atividades. Igualmente deverão ser importantes a organização escalar e a distribuição de tarefas. Conseqüências pouco animadoras do ethos burocrático do militar, enquanto dirigente de emprêsas industriais, seriam a inevitável falta de criatividade que se apresenta como corolário da burocracia, apêgo a uma estrutura existente e morosidade na sua transformação. A transformação da burocracia ocorrerá, quase que fatalmente, por via burocrática.

O processo decisório tenderá a ser pôsto de maneira institucionalizada, isto é, haverá um grande apêgo às decisões de tipo programado e um grande esfôrço para converter as decisões não programadas em programadas, e que, conseqüientemente pudessem ser mais fàcilmente tratadas. 
A delegação de autoridade e a participação dos níveis intermediários no processo decisório são conseqüência da burocracia, que se apóia na divisão do trabalho. Dêste ponto de vista, as probabilidades de transformar-se a emprêsa numa "equipe para tomar decisão" são maiores para a de economia mista do que para a emprêsa familiar brasileira. Estas probabilidades tenderão a aumentar à medida que a dinamização destas emprêsas, introduzidas pela adoção de nova tecnologia, obrigue um número maior de especialistas ou tecnocratas a adentrar os quadros organizacionais.

\section{CONCLUSÓES}

É um dado da experiência ser a competição um princípio saudável na atividade econômica, quando esta se estrutura sob forma de economias de mercado. A sua defesa, inclusive pela legislação de países em que predomina uma economia de mercado, constitui um espécie de instinto de conservação, contra os riscos de imobilismo e relativa estagnação do sistema que adviriam de situações de monopólio. Os setores industriais onde se tem de fazer concessão ao monopólio, são, em regra, os menos dinâmicos de uma economia. Os riscos em que se incorre, quanto à eficiência de um sistema econômico onde se suprime a competição, são grandes, e o aumento desmedido e a hipertrofia dos setores de serviços das economias dos países socialistas constituem problema ainda não solucionado. A competição exigindo maior desenvoltura empresarial, a fim de permitir que um determinado número de emprêsas continue no mercado, provoca maior criatividade e modificações nos métodos de tomada de decisão. $O$ número de pessoas, de técnicas e de processos que precisam ser utilizados a fim de manter uma emprêsa operando em regime de genuína competição levam à formação de emprêsas que adquirem o aspecto de "equipes para tomar decisão", afastando a possibilidade de um esclerosamento permissível pela manipulação de decisões programadas. 
À medida que uma economia, ainda periférica como a brasileira, fôr capaz de tornar-se efetivamente competitiva, o processo decisório tenderá a modificar-se e os padrões de repetição de procedimentos e de apêgo às decisões programadas tenderão a ser postos de lado. Infelizmente, uma série de circunstâncias, que seria ocioso enumerar, mas dentre as quais cumpre destacar o baixo poder aquisitivo do mercado, ainda tornam a competição inexequível na maioria das indústrias, pois seria impossível realizar as respectivas economias de escala.

O aumento puro e simples do tamanho físico das emprêsas obriga a modificação da estrutura organizacional e dos procedimentos para a tomada de decisões. Mesmo que os sistemas de comunicação fôssem adequados, o que infelizmente não ocorre em nosso país, há a necessidade de se dar maior autoridade para que os indivíduos responsáveis pelas operações das várias unidades procedam com mais autonomia, particularmente mais ativamente no processo de tomada de decisões. Acreditamos que muitas emprêsas em nosso país têm o seu crescimento sèriamente ameaçado e não chegam a expandir-se, não tanto devido à falta de mercado, mas porque os seus proprietários não logram um sistema de descentralização em que se dê às sucursais ou filiais suficiente participação no processo de tomada de decisões.

O aumento de pessoas que possuem educação de nível universitário e que passam a integrar o quadro de uma emprêsa é fator que leva também a modificações no processo decisório. Por mais que se critique o sistema de educação superior vigente no Brasil, particularmente a sua falta de criatividade e o fato de não preparar os seus licenciados para uma vida intelectual realmente autônoma, sempre é maior a capacidade de pensar mais livremente de assumir responsabilidades e, portanto, de integrar uma "equipe para tomar decisão" entre os que passaram por uma universidade do que entre pessoas que foram privadas de tal benefício. Além do mais, a educação superior 
sempre fornece ao indivíduo maior senso crítico e desenvolve uma tendência à não aceitação pura e simples de procedimentos por razões exclusivamente tradicionais. $O$ homem que passou por um sistema universitário sempre terá maiores probabilidades de vir a inovar que os demais.

- Outro fator a contribuir para que se modifique a estrutura organizacional e os procedimentos para tomada de decisões em nosso país é o próprio processo de industrialização e a conseqüente urbanização, enquanto elementos modificadores do ethos cultural. Não seria descabido recordar que o Brasil é país que poderia ser fàcilmente catalogável como dotado de um ethos rural mais do que urbano.

Os cientistas sociais que se aplicaram ao estudo de nossa evolução histórica e social reconhecem que o predomínio da sacralidade rural sôbre o laicismo urbano constituíram uma constante em nosso processo de urbanização, ao longo de quase tôda a história nacional, fato que se modifica apenas com o início da industrialização. Os padrões autocráticos e patriarcais, que ainda podemos encontrar no interior de emprêsas familiares brasileiras, constituem uma transposição dêsse ethos rural para a vida da emprêsa. O nôvo capitão de indústria, ou líder financeiro, colocado à frente de alguma rêde bancária, continua a adotar e criar a expectativa de que os mesmos padrões de monopólio decisório permaneçam em tôrno de si mesmo ou de uma diretoria por êle presidida. A vinda de um número cada vez maior de pessoas para os centros urbanos, que se criam e aumentam por fôrça do processo de industrialização, funciona como centro onde o ethos rural sofre fatal desgaste, abrindo perspectivas para que novas formas decisórias se instalem nas emprêsas.

- Finalmente, cumpre destacar o papel de importância a ser desempenhado por instituições que ocupam posição de liderança no processo social, enquando introdutoras de modificações. No caso de inovações organizacionais e que 
repercutem sôbre as práticas decisórias das emprêsas, cumpre destacar as escolas de nível superior que têm como função precípua exercer ação renovadora e algumas emprêsas estrangeiras, que, apesar de não adotarem no país periférico os mesmos padrões decisórios e administrativos que fazem prevalecer nos países cêntricos, sempre marcam um avanço com relação às práticas habituais das emprêsas nacionais de tipo familiar. 